DOI: https://doi.org/10.24144/2409-6857.2018.2(52).26-31

УДК 338.43:338.48:330.341:005.583.3

Молнар О. С, Важинський Ф. А., Микулянець В.І.

\title{
СТИМУЛЮВАННЯ РОЗВИТКУ НЕСІЛЬСЬКОГОСПОДАРСЬКОЇ ЗАЙНЯТОСТІ В СІЛЬСЬКІЙ МІСЦЕВОСТІ УКРАЇНИ
}

\begin{abstract}
У статті визначені можливості розвитку різних видів несільськогосподарської зайнятості в сільській місиевості Украӥни. Розглянуто основні заходи щуодо стимулювання несільськогосподарської зайнятості. Визначено, щуо актуальним видом несільськогосподарської зайнятості, який може не тільки суттєво зменшити безробіття, але й змінити інфраструктуру села, а з часом стати одним із основних джерел доходів для селян - є сільський туризм. Виявлені проблеми, які відображають сам зміст сочіальної сфери. Розглянуто формування нових сочіально-економічних відносин на сільських територіях $і$ визначено, що ефективним ресурсом розвитку сільських територій в сучасних умовах може стати сочіальне партнерство. Окреслені основні напрямки розвитку сільських територій.
\end{abstract}

Ключові слова: сільські території, сільське господарство, безробіття, сочіальна інфраструктура, зайнятість, сільський туризм, сочіальне партнерство, коопераџія, підприємства, диверсифікація.

Постановка проблеми. Ринкова трансформація економіки гостро поставила перед Україною проблему вибору ефективних напрямів та інструментів забезпечення сталого розвитку сільських територій.

Основним видом виробництва на сільських територіях є аграрне виробництво. У сільському господарстві України існує ще багато невирішених проблем. В галузі зберігається багато збиткових господарств, найнижча заробітна плата, залишається низьким рівень використання сільськогосподарських угідь, досить слабким $\epsilon$ соціальний захист селян порівняно з іншими галузями економіки.

Однією із причин бідності сільського населення та демографічної кризи на селі $\epsilon$ безробіття. Безробіття означає прямі економічні втрати для всього суспільства: скорочення обсягу національного продукту, уповільнення зростання добробуту, поглиблення майнової диференціації.

Через економічну кризу в країні, збитковість сільськогосподарських підприємств, зубожіння сільського населення та мізерність бюджетного фінансування руйнується і занепадає соціальна інфраструктура села. Закриваються школи, лікарні, фельдшерсько-акушерські пункти. Все це ускладнює доступ все більшої кількості селян до життєво необхідних послуг. Подолання проблем

\footnotetext{
Молнар Олександр Сергійович, к.е.н., доц, завідувач кафедри економічної теорії, ДВНЗ «Ужгородський національний університет», м.Ужгород

Важинський Федір Анатолійович, к.е.н,, с.н.с., ДУ "Інститут регіональних досліджень ім. М.І. Долішнього НАН України", м.Львів

Микулянець Вікторія Іванівна, студент магістерської програми кафедри фінансів i банківської справи ДВНЗ «Ужгородський національний університет», м.Ужгород
}

низької ефективності аграрної політики, дефіциту коштів у бюджеті країни на соціальні витрати, повільного становлення сільського самоврядування, віддаленості селян від ринків збуту сільськогосподарської продукції, обмеженості доступу до матеріально-технічних, фінансових та інформаційних ресурсів вимагає посиленої уваги щодо вирішення цих проблем на сільських територіях.

Аналіз останніх досліджень і публікацій. Визнаними вченими у сфері дослідження розвитку сільських територій $€$ О.А. Біттер, О.Г. Булавка, П.І. Гайдуцький, О.Д. Гудзинський, М.Ф. Кропивко, Е.М. Лібанова, М.Й. Малік, М.К. Орлатий, І.В. Прокопа, П.Т. Саблук, М.П. Сахацький, В.К. Терещенко, В.В. Юрчишин та інші.

Але, незважаючи на посилену увагу науковців до проблем села, недостатньо повно ще досліджені питання вивчення стратегічних засад розвитку сільських територій і тому потребують подальших досліджень.

Формулювання цілей статті. Мета статті визначити основні напрями розвитку сільських територій.

Опис основного матеріалу дослідження. Розвиток сільських територій $є$ комплексним завданням, але його можна звести до вирішення двох основних проблем: розвитку сільської соціальної сфери та підтримки економічного розвитку села.

Підтримувати сільськогосподарське виробництво і одночасно фінансувати соціальну сферу наша держава не в змозі.

Для України реальною $є$ загроза стати сировинним придатком та ринком збуту високотехнологічної імпортної продукції. Тенденції світової економіки вказують на те, що в 
перспективі нас чекає подальше загальносвітове подорожчання енергоносіїв, збільшення посівних площ сільськогосподарських культур, які $\epsilon$ сировиною для біопалива i, відповідно, підвищення дефіцитності продуктів харчування і зростання світових цін на них. Отже рентабельність сільськогосподарського виробництва зростатиме, а тому державну підтримку необхідно надавати не сільському господарству, а вкладати бюджетні кошти в наукомісткі технології, освіту, сферу послуг, розвиток несільськогосподарських видів діяльності на сільських територіях.

Несільськогосподарська зайнятість $\epsilon$ важливим джерелом зайнятості на селі та можливістю підвищити доходи сільського населення, а відтак і стандарти життя в селах України. В більшості розвинених країн населення сільських поселень зайняте переважно несільськогосподарською діяльністю. В Україні майже все сільське населення займається часто неефективним малопродуктивним сільським господарством. Тому розвиток зайнятості в несільськогосподарському секторі сільської місцевості повинен стати стрижнем політики розвитку сільських територій.

Розвиток різних видів несільськогосподарської зайнятості в сільській місцевості поряд із зниженням рівня безробіття, дає можливість позбутися ще кількох важливих соціальних та економічних проблем, зокрема:

- зменшиться соціальна напруженість у суспільстві, викликана різкою диференціацією доходів. Безробітні селяни ні в якому разі не повинні звикати до пасивного становища дармоїдів, інакше вони втратять будь-які стимули змінювати життя на краще;

- через підвищення зайнятості, зросте купівельна спроможність селян, а за рахунок цього розшириться коло та збільшиться обсяг споживання сільськогосподарської та промислової продукції, надання соціальних послуг;

- збільшаться надходження до сільських бюджетів, що дасть змогу формувати бюджети розвитку, а не проїдання. Маючи гроші і реально здійснюючи відновлення та розвиток соціальної інфраструктури, допомагаючи соціально вразливим категоріям населення, сільська рада підвищить свій статус і відновить повагу населення до влади;

- підвищення зайнятості збільшує доходи населення, які можуть бути інвестовані в соціальну інфраструктуру села, в сферу надання платних послуг. Держава не може фінансувати соціальну інфраструктуру села в повній мірі.

В той час як сільське господарство є головним для сільського населення, несільськогосподарський сектор та дохід від нього також поступово стають все більш важливими. Значна частка сільського населення офіційно зайнята в сільському господарстві, всі види несільськогосподарської зайнятості (переробна галузь, оптова та роздрібна торгівля, транспорт, освіта, охорона здоров'я тощо) в сумі забезпечують роботою до $20 \%$ селян [1].

3 іншого боку, більшість сільського населення не $\epsilon$ зайнятим. Ця категорія населення охоплює тих, хто шукає, але не може знайти роботу, пенсіонерів, школярів, студентів тощо. Але потрібно зважати на специфіку сільського життя в Україні. Більшість сільських домогосподарств, включаючи тих, хто зайнятий в несільськогосподарському секторі, витрачають значну частину свого часу на працю в особистому господарстві.

Таким чином, майже все сільське населення в Україні офіційно чи неофіційно працює в сільському господарстві. При умові ефективного i раціонального використання природного багатства та проведення адекватної аграрної політики, сільське господарство 3 часом перетвориться на конкурентноздатний сектор виробництва.

Підвищення рівня сільського безробіття, за відсутності нових робочих місць, означає серйозні соціальні та економічні проблеми для уряду: зростання бідності на селі, активізацію міграції, зменшення податкової бази для сільських податків, тощо. Несільськогосподарська зайнятість має потенційні можливості зменшення цих загроз.

Стимулювання несільськогосподарської зайнятості $\epsilon$ комплексним завданням. Основні заходи щодо стимулювання несільськогосподарської зайнятості необхідно здійснювати на місцевому рівні. Органам державної влади та місцевого самоврядування в напрямі стимулювання несільськогосподарської зайнятості пропонується:

- проведення політики стимулювання працевлаштування в несільськогосподарських галузях виробництва;

- забезпечення прав власності та використання природних ресурсів;

- покращення інфраструктури та загальних умов діяльності на сільських територіях, замість допомоги окремим підприємствам;

- спрямовування ресурсів на розвиток несільськогосподарської зайнятості не в ті сільські поселення, які мають потенціал зростання, а в депресивні, що мають низький рівень розвитку інфраструктури, незадовільну 
якість підготовки робочої сили, недосконалі умови для переробки продукції та маркетингу.

Актуальним видом несільськогосподарської зайнятості, який може не тільки суттєво зменшити безробіття, але й змінити інфраструктуру села, а 3 часом стати одним із основних джерел доходів для селян - $\epsilon$ сільський туризм.

Сільський туризм - це не тільки проживання туриста в сільському будинку, але й функціонування цілої інфраструктури, включаючи добре транспортне сполучення, місця проведення дозвілля, інформаційні послуги, ресторани, кафе [6].

Сьогодні сільський туризм розвивається дуже швидкими темпами і в деяких країнах привертає значну частину іноземних туристів. Як особливо яскраві приклади можуть бути названі Італія, Іспанія, Ірландія, Франція, Швейцарія.

Італія - визнаний європейський лідер по сільському туризму. В 70 -х роках минулого століття передбачалося, що розміщення туристів буде непрофільною діяльністю для італійських селян i лише дещо укріпить їх фінансовоекономічне становище. Проте сьогоднішній попит змінив саму концепцію сільського туризму, який перетворився для багатьох сільських жителів в основний вид діяльності.

В Іспанії діє національна програма по розвитку цього виду відпочинку. Для значної частини іспанських селянських господарств (60\%) агротуризм є одним з основних джерел доходу.

Сьогодні, практично будь-яка подорож по Швейцарії, в якійсь мірі - сільська. Без туризму величезні гірські території вже давно обезлюдніли б, зникла б торгівля і сільське господарство втратило б всяку традиційність та стійкість.

Проте, не тільки високий попит на даний вид послуг дав поштовх розвитку сільського туризму в Європі. Сьогодні Європейський Союз бачить можливість економічного підйому села саме в сільському туризмі. Сьогодні в Західній Європі налічується приблизно стільки ж ліжко-місць для відпочиваючих в сільській місцевості в будинку господарів, скільки і в готелях.

В Україні, ситуація складніша. Депресія в сільському господарстві, високе безробіття в сільській місцевості, відсутність належного фінансування вимушує уряд шукати нові рішення проблем. А сільський туризм $є$ частиною внутрішніх джерел інвестицій для підтримки життя в селі. Це і нові робочі місця, і надходження валюти, і розвиток інфраструктури, і підвищення культурно-освітнього рівня. Спілкування 3 місцевим населенням дасть можливість більше дізнатись про свої корені, свою країну - природу, побут, культуру [6].

Україна володіє ресурсами, необхідними для розвитку агротуризму. Визначні пам'ятки України роблять її вкрай привабливою країною для всіх видів туризму: краса природи (озера, річки, ліси), доброзичливе, гостинне населення, різноманіття агроландшафтів, своєрідна культурно-історична спадщина.

Транспортне сполучення в Україні відносно розвинуте (авіа, залізничний, морський, річковий, автомобільний транспорт) і не $є$ перешкодою для розвитку агротуризму. $Є$ в наявності карти всіх регіонів. Відсутні проблеми 3 візами для іноземних туристів. Таким чином, потенційний попит і ресурси для розвитку сільського туризму в Україні є. Є і гостра економічна необхідність в цьому.

Зараз особливо важлива програма просування самої ідеї агротуризму в Україні в цілому. Метою iii повинне бути - підвищення обізнаності населення і створення позитивного відношення до цього виду відпочинку. В першу чергу повинні бути задіяні такі види маркетингових комунікацій як PR-статті, інтерв'ю, прес-конференції, семінари, брифінги, телепередачі.

На сучасному етапі ринкових перетворень в Україні зберігається тенденція недофінансування галузей соціальної інфраструктури. Найбільш яскраво це виявляється в селі. 3 точки зору соціального чинника перед економікою стоять наступні проблеми, які відображають сам зміст соціальної сфери:

- як задовольняти потреби людей;

- як забезпечити справедливий розподіл благ;

- як досягти злагодженості між ростом добробуту та підвищенням ефективності економіки.

Оскільки економічний розвиток здатний забезпечити великі можливості задоволення соціальних потреб, а активне соціальне життя сприяє підтримці високої економічної активності, тому оптимізація виробничої діяльності передбачає, що економічна та соціальна ефективність мають бути узгоджені. Економічне життя повинне орієнтуватися на розвиток людського фактора. Проте практика свідчить, що реалізація його найважливіших соціальноекономічних прав, творчого потенціалу, залишаються в глибокій соціально-економічній кризі. Для зниження рівня бідності і створення умов зростання середнього класу держава повинна активно впливати на рівень оплати праці. Його підвищення розвиває у працедавців стимули до більш ефективного використання робочої сили до впровадження нової продуктивної техніки, зростання технічного рівня виробництва, поліпшення умов праці, що об'єктивно вимагає 
активного розвитку соціальної сфери.

Розглянемо формування нових соціальноекономічних відносин на сільських територіях.

Якісний стан підприємств соціальної інфраструктури села (шкіл, лікарень, установ культури і т.д.) та можливість їх розвитку в майбутньому в значній мірі залежить від того наскільки стабільно i ефективно вони функціонують в умовах ринку, що формується. Поки що вони слабо реагують на змінні ринкові умови i повністю залежать від державної підтримки.

Перехід до фінансування підприємств соціальної інфраструктури села за рахунок коштів приватних інвесторів і населення не підкріплений реальними механізмами та неадекватний існуючій соціально-економічній ситуації третина сільськогосподарських підприємств $\epsilon$ хронічно збитковими і не готові до підтримки соціальної сфери, а більшість сільського населення за межею бідності. Підприємства соціальної інфраструктури села як i раніше фінансуються за залишковим принципом, $\epsilon$ хронічно збитковими і дотепер не розроблені реальні механізми їх підтримки.

Особливих труднощів зазнають жителі малих і середніх сіл депресивних районів, які внаслідок транспортної віддаленості і відсутності коштів, позбавлені мінімуму соціальних послуг.

В результаті проведених трансформацій вже стало зрозумілим, що ні держава - в особі органів місцевого самоврядування, ні бізнес - в особі сільськогосподарських та інших підприємств, ні підприємства та організації соціальної інфраструктури села не можуть “поодинці" розв'язати проблеми виведення 3 кризи соціальної сфери села.

За останні роки питанням стратегій соціальноекономічного розвитку сільських поселень надавали увагу багато державних і міжнародних організацій, проте вирішення місцевих соціальноекономічних проблем залежить, в першу чергу, від самих сільських громад. Вони можуть поліпшити ситуацію в селі, відмовившись від утриманських настроїв, 3 допомогою власної ініціативності та підприємництва. На шляху до цього існують наступні проблеми:

1. Нерозвиненість інститутів громадянського суспільства при виробленні рішень та проведенні суспільно-економічних перетворень. Рішення, що приймаються владою без урахування думки сільської громади, по-перше, не завжди відображають їі інтереси, а по-друге, зустрічають опір селян і залишаються невиконаними.

2. Відсутність стратегічного планування в селах. Ефективність перетворень могла б бути набагато вищою при переході до збалансованих програм розвитку сільської економіки та соціального життя, розроблених за принципами стратегічного планування 3 урахуванням побажань кожного члена сільської громади.

3. Недостатне використання місцевих сільських ресурсів розвитку. Майже не використовуються в сільській економіці нерухомість, сільська інфраструктура, не покращується інвестиційний клімат для розвитку підприємництва.

Ефективним ресурсом сільського розвитку в сучасних умовах може стати соціальне партнерство. Під соціальним партнерством розуміється конструктивна взаємодія представників влади, бізнесу та населення при вирішенні соціально важливих проблем, що здійснюється в межах закону з метою проведення раціональної соціальної політики. Значення соціального партнерства полягає в налагодженні конструктивної взаємодії між трьома силами сільською владою, підприємцями і населенням.

Таким чином, в даний час основною проблемою для сільських органів самоврядування $\epsilon$ не стільки розробка стратегічних планів сільського соціально-економічного розвитку, скільки їх соціальна адаптація, а також залучення грошових коштів організацій та населення для впровадження цих планів в режимі соціального партнерства. Такий підхід є єдино можливим для сільських рад, щоб їх плани не залишилися на папері, а були реалізовані.

Криза, відсутність коштів і відомчої опіки спонукає органи місцевого самоврядування до пошуку та впровадження інноваційних технологій, що забезпечують стабільність підприємств і організацій соціальної інфраструктури села та умови для їх ефективного розвитку в майбутньому.

В умовах малого села, де обмежений вибір робочих місць, наявність ресурсів для розвитку певних сфер діяльності виконує провідну роль. Ресурси: земля, ліс, надра в селах знаходяться у віданні сільських рад. Сільськогосподарські підприємства $є$, як правило, єдиним джерелом зайнятості місцевих жителів. Для підтримки стабільності підприємств необхідні: ресурси - для забезпечення робочих місць і послуги соціальної інфраструктури - для життєдіяльності населення. Таким чином місцеві органи самоврядування, сільськогосподарські підприємства і підприємства соціальної інфраструктури вимушені взаємодіяти. В результаті виникає основа для використання механізму соціального партнерства, тобто взаємної відповідальності і готовності до відшкодування ризиків партнерів по бізнесу у здійсненні спільної соціальної діяльності. 
Використання механізму партнерства в пошуку технологій виходу 3 кризи є особливо ефективним. Органи місцевого самоврядування вимушені йти на взаємодію 3 сільськогосподарськими підприємствами, бо вони не мають достатніх фінансово-матеріальних ресурсів для розвитку об'єктів соціальної інфраструктури села. Сільські підприємства із-за скрутного матеріального становища часто також не можуть фінансувати розвиток соціальної сфери. У цих умовах залишається лише взаємний обмін послугами соціальної i виробничої структур села як засіб збереження інфраструктури села i забезпечення життєдіяльності сільських громад.

Впровадження моделі соціального партнерства створить основу для взаємодії та узгодження інтересів органів місцевого самоврядування, сільськогосподарських підприємств i організацій та установ соціальної інфраструктури для забезпечення їх взаємної стабільності на місцях. Ї̈̈ широке використання в селах дозволить укріпити функціональні можливості та підвищити ефективність ухвалення рішень на рівні органів місцевого самоврядування, сільськогосподарських підприємств та підприємств соціальної інфраструктури села. В результаті взаємодії і партнерства різних секторів в рамках сільських поселень поступово створиться середовище для розвитку корпоративних відносин та формування внутрішніх джерел по виведенню 3 кризи віддалених депресивних сільських територій.

Основними напрямами розвитку сільських територій $\epsilon$ :

- реформування адміністративно-територіального устрою 3 метою наближення адміністративних і соціальних послуг до сільського населення, децентралізація бюджетної системи;

- створення на сільських територіях господарських систем, що саморозвиваються, на підставі економічного обороту місцевих ресурсів, диверсифікація сільськогосподарського виробництва, розвиток промисловості 3 переробки сільськогосподарської сировини, активізація несільськогосподарської зайнятості, підвищення економічної активності населення, відродження традиційних та розвиток нових ремесел, промислів і виробництв;

- розвиток сучасної виробничої та інформаційної інфраструктури, кооперації господарств у виробничій, збутовій, фінансовій та інших сферах;

- розвиток місцевого самоврядування для формування соціально організованої та відповідальної сільської громади, підвищення привабливості проживання в сільській місцевості.

Висновки i перспективи подальших досліджень. Реальна ефективність соціальної політики можлива лише при активній ролі сільських рад. Тільки вони в змозі оцінити потреби території в тих або інших послугах i необхідності використання відповідних технологій та механізмів для їх підтримки i розвитку соціальної інфраструктури. Тільки через сільські ради, у компетенції яких соціальноекономічний розвиток території, можна впровадити реальні технології, що забезпечують взаємну стабільність різних секторів села. Це дозволить змістити центр ухвалення рішень на рівень місцевого самоврядування, сформувати соціальну політику, яка базується на реально наявних ресурсах і можливостях, $\epsilon$ економічно спроможною, стимулюючою, а не обмежуючою економічне зростання.

Підтримувати сільськогосподарське виробництво і одночасно фінансувати соціальну сферу наша держава не в змозі, тому бюджетні кошти необхідно вкладати в першу чергу у наукомісткі технології, сферу послуг, освіту, розвиток інших видів несільськогосподарської діяльності на сільських територіях.

Одним із нових, і в той же час, актуальних видів несільськогосподарської зайнятості, який може не тільки суттєво зменшити безробіття, але й змінити інфраструктуру села і можливо навіть 3 часом стати одним із основних джерел доходів для селян $-\epsilon$ сільський туризм.

Ефективним ресурсом розвитку сільських територій в сучасних умовах може стати соціальне партнерство - конструктивна взаємодія представників всіх трьох секторів будь-якого суспільства (державного, комерційного та некомерційного) при вирішенні соціально важливих проблем, що здійснюється в рамках чинного законодавства i направлена на проведення раціональної соціальної політики.

\section{ПЕРЕЛІК ВИКОРИСТАНИХ ДЖЕРЕЛ}

1. Агропромисловий комплекс України: стан, тенденції та перспективи розвитку : інформаційно-аналітичний збірник. Вип. 6 / за ред. П.Т. Саблука. - К. : ІАЕ УААН, 2003. - 764 с.

2. Важинський Ф.А. Диверсифікація та кооперація розвитку сільських територій регіону / Ф.А. Важинський, А.В. Колодійчук, О.С. Молнар // Наук. вісник Ужгород. ун-ту : зб. наук. пр. - Сер.: Економіка. - 2011. - Вип. 33, 
ч. 3. - С. 125-129.

3. Важинський Ф.А. Зарубіжний досвід розвитку територіально-виробничих систем / Ф.А. Важинський, О.О. Жовтанецька, А.В. Колодійчук // Науковий вісник НЛТУ України. - 2007. - Вип. 17.3. - С. 141-145.

4. Важинський Ф.А. Механізм регулювання інвестиційної діяльності в регіоні / Ф.А. Важинський, А.В. Колодійчук // Науковий вісник НЛТУ України : зб. наук.-техн. праць. - Львів: РВВ НЛТУ України. - 2010. - Вип. 20.7. - С. 138-143.

5. Гаврилко П.П. Фактори інноваційного розвитку промисловості / П.П. Гаврилко, А.В. Колодійчук, В.М. Черторижський // Науковий вісник НЛТУ України: зб. наук.-техн. праць. - 2011. - Вип. 21.11. - С. 201-205.

6. Гайдуцький П.І. Аграрна реформа в Україні / П.І. Гайдуцький, П.Т. Саблук, Ю.О. Лупенко [та ін.]. - К. : ННЦ IАЕ, 2005. - 424 c.

7. Долішній І.М. Мотивація персоналу як об’єкт управління на підприємстві / I.М. Долішній, А.В. Колодійчук // Науковий вісник НЛТУ України. - 2010. - Вип. 20.5. - С. 211-216.

8. Колодійчук А.В. Сутність інновацій, структура та основні етапи інноваційного процесу / А.В. Колодійчук, В.М. Пісний, Ж.В. Семчук // Науковий вісник НЛТУ України. - 2009. - Вип. 19.9. - С. 191-196.

9. Мельник С. І. Соціально-економічні проблеми відтворення та ефективного використання ресурсного потенціалу села / С. І. Мельник - К. : ННЦ “ІАЕ”, 2004. - 428 с.

\section{REFERENCES}

1. Sabluk, P. T. (Ed.) (2003). Ahropromyslovyy kompleks Ukrayiny: stan, tendentsiyi ta perspektyvy rozvytku [Agro-industrial complex of Ukraine: state, trends and prospects of development] (Information-analytical collection). Vol. 6. Kyiv: National Scientific Center "Institute of Agricultural Economics" of Ukrainian Academy of Agrarian Sciences. [in Ukrainian].

2. Vazhynskyy, F. A., Kolodiychuk, A. V., \& Molnar, O. S. (2011). Dyversyfikatsiya ta kooperatsiya rozvytku sil's'kykh terytoriy rehionu [Diversification and co-operation of the development of rural areas of the region]. In Naukovyy visnyk Uzhhorods'koho universytetu. Seriya: Ekonomika [Scientific Bulletin of Uzhhorod University. Series: Economics]: Vol. 33(3) (pp. 125-129). [in Ukrainian].

3. Vazhynskyy, F. A., \& Kolodiychuk, A. V. (2010). Mekhanizm rehulyuvannya investytsiynoyi diyal'nosti v rehioni [Mechanism for regulation of investment activity in the region]. In Naukovyy visnyk NLTU Ukrayiny [Scientific Bulletin of National Forestry University of Ukraine]: Vol. 20.7 (pp. 138-143). [in Ukrainian].

4. Vazhynskyy, F. A., \& Kolodiychuk, A. V. (2010). Mekhanizm rehulyuvannya investytsiynoyi diyal'nosti v rehioni [Mechanism for regulation of investment activity in the region]. In Naukovyy visnyk NLTU Ukrayiny [Scientific Bulletin of National Forestry University of Ukraine]: Vol. 20.7 (pp. 138-143). [in Ukrainian].

5. Havrylko, P. P., Kolodiychuk, A. V., \& Chertoryzhskyy, V. M. (2011). Faktory innovatsiynoho rozvytku promyslovosti [Factors of innovation development of industry]. In Naukovyy visnyk NLTU Ukrayiny [Scientific Bulletin of National Forestry University of Ukraine]: Vol. 21.11 (pp. 201-205). [in Ukrainian].

6. Haydutskyy, P. I., Sabluk, P. T., Lupenko, Yu. O., \& et al. (2005). Ahrarna reforma v Ukrayini [Agrarian reform in Ukraine]. Kyiv: National Scientific Center "Institute of Agricultural Economics" of Ukrainian Academy of Agrarian Sciences. [in Ukrainian].

7. Dolishniy, I. M., \& Kolodiychuk, A. V. (2010). Motyvatsiya personalu yak ob"yekt upravlinnya na pidpryyemstvi [Motivation of the personnel as an object of management at the enterprise]. In Naukovyy visnyk NLTU Ukrayiny [Scientific Bulletin of National Forestry University of Ukraine]: Vol. 20.5 (pp. 211-216). [in Ukrainian].

8. Kolodiychuk, A. V., Pisnyy, V. M., \& Semchuk, Zh. V. (2009). Sutnist' innovatsiy, struktura ta osnovni etapy innovatsiynoho protsesu [The essence of innovation, the structure and the main stages of the innovation process]. In Naukovyy visnyk NLTU Ukrayiny [Scientific Bulletin of National Forestry University of Ukraine]: Vol. 19.9 (pp. 191196). [in Ukrainian].

9. Melnyk, S. I. (2004). Sotsial'no-ekonomichni problemy vidtvorennya ta efektyvnoho vykorystannya resursnoho potentsialu sela [Socio-economic problems of reproduction and effective use of the rural resource potential]. Kyiv: National Scientific Center "Institute of Agricultural Economics" of Ukrainian Academy of Agrarian Sciences. [in Ukrainian].

Одержано 12.09.2018 p. 